\title{
LYSIAS IN ATHENS
}

Lysias is as prominent a figure in the Greek rhetorical tradition and prose canon as he is a shadowy one. While surely among the most widely read Greek authors, we do not really know much about him and questions around the authorship of the so-called Lysianic corpus have troubled critics since antiquity. In fact, the large number of speeches that had been attributed to him by the first century BCE prompted Dionysius of Halicarnassus to have a longer discussion of the methods of testing Lysianic authorship (Lysias IO-I2). ${ }^{\text {I }}$ Throughout antiquity and until the mid-twentieth century, the absence of solid biographical information and of any conclusive evidence about the author did not prevent scholars from constructing full-scale narratives about Lysias' life and works, mostly based on Lysias' own speeches and possible reconstructed encounters with other contemporary intellectuals. ${ }^{2}$ It was the groundbreaking (and highly controversial) work by Kenneth Dover

${ }^{\text {I }}$ Ps. Plutarch, Lives of Ten Orators 836a claims to know of 425 speeches circulating under the name Lysias. He also reports there that Dionysius cut the number of authentic speeches down to 233.

${ }^{2}$ In the ancient biographical tradition, for example, Ps. Plutarch's account offers more biographical details, reported with higher certainty, than we see in Dionysius. He reports, for example, the names of Lysias' grandfather and great-

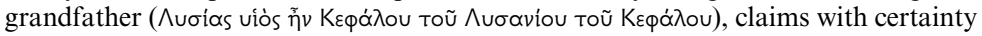

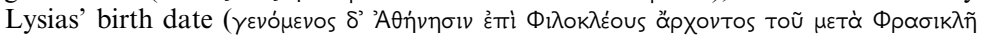

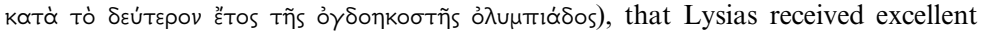
education in Athens and later instruction in rhetoric from Tisias and Nicias (кỏk

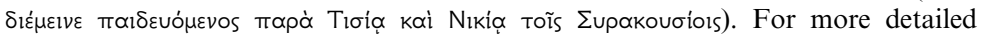
discussion, see Schindel (I967), esp. 33-4I; Todd (2007), 8 n. 29. Useful appraisal of Ps. Plutarch's mode of writing and its relationship to different source texts is Pitcher (2005). Edwards (I998) persuasively argues for a more positive evaluation of the whole Ps. Plutarchan project. Closer to contemporary times, Blass (I868) constructs in his authoritative account of Greek orators a detailed bibliographical account of Lysias' life: 'Ueber die Lebensumstände dieses Mannes haben wir ziemlich reichhaltige Quellen' (33I). 
which brought about a change in Lysias studies. ${ }^{3}$ He argued for a very different view of Lysias (and, as Usher noted, ${ }^{4}$ implicitly of all Attic orators) by questioning the ability of the existing texts to point us towards the 'actual' speeches of the historical Lysias. In his skepticism, Dover's work was very much in keeping with the contemporary preoccupations and literary theories of the I96os. Dover argues that the attribution of works to Lysias and the building up of his corpus to the size that Dionysius reports by the first century $\mathrm{BCE}$ was a process that had started already during the orator's lifetime, and that there was probably a particular boost for literary forgeries to be passed off under Lysias' name immediately after his death. ${ }^{5}$ In other words, through the examination of chronology, ideology and artistry, Dover concluded that there is very little that we can say with full confidence about Lysias and, in particular, about Lysias' authorship of the speeches in the corpus. The many stages that go into the emergence of a text, from the litigant to the speechwriter to the bookseller to publication, processes that we generally ignore for the sake of simplicity, ${ }^{6}$ are all highly susceptible to modification and could easily cast a shadow on any comfortable attribution of texts to an author 'Lysias' whom we actually know very little about.

There are problems with this view that have since been highlighted by others. For example, Dover uses pervasively the concept of a 'consultant' for the Greek translation of

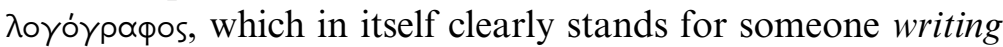
the speech (rather than an advisor); in subsequent criticism, Lysias is regarded as the writer and author of these speeches, and we see no hint in Dionysius of Halicarnassus' treatment of Lysias for a view of Lysias as a consultant and not a prose artist. ${ }^{7}$ Dover's challenge, which was met with significant

\footnotetext{
3 Dover (I968). $\quad{ }^{4}$ In his response to Dover's Corpus Lysiacum, Usher (I976), 40.

5 Dover (I968), 23-7.

${ }^{6}$ Or because we 'have become accustomed to treat oratory as if it were philosophy, history, poetry or technical literature' (I95-6).

7 Many more arguments have been brought against Dover's thesis. It is worth mentioning also Kennedy's suggestion $($ I970, 497) that speeches were out there to benefit the writer and so it was more likely that the speechwriter had a final say about the published form. Usher (I976) evokes some anecdotes about speechwriting
} 
resistance upon its publication, has nevertheless been a productive one and has since pushed scholars further to explore the less visible elements of rhetorical practice. ${ }^{8}$

Lysias' corpus has since been fruitfully examined as a historical source for this extremely fascinating time period (c.403-380 BCE) for which it provides valuable and unique information, thus offering a rare window into the actual lives of Athenians. ${ }^{9}$ In this context, it has mattered less whether or not the author of these speeches is Lysias or somebody else trying to come off as Lysias, as long as the texts could be relatively securely dated to the fourth century BCE. This approach would have been unusual for ancient critics, who looked at the orators primarily (if not exclusively) as masters of style and rhetoric. ${ }^{\text {IO }}$ The earliest moment of Lysias' reception in Plato's Phaedrus, which in many ways (as will be argued below) came to determine the orator's name and reception for posterity, is a good example. This chapter will follow the figure of Lysias and his image that emerges through his own writings but in particular through his reception in the works of others. In other words, we will not try to establish historical information about the actual person Lysias who lived and wrote in Athens of the fifth and fourth centuries

that similarly indicate that the traditional view of speechwriting was more common in the ancient sources. In general, the most straightforward rejection of Dover's suggestion after the publication of Corpus Lysiacum was Usher (I976), which should still be read alongside Dover's book, as it brings many reasonable counterarguments against Dover's composite authorship hypothesis. Todd provides a useful recent assessment of Dover's claims and the responses and criticisms made against it $(2007,28-9)$. Todd is certainly more optimistic about the authenticity of Lysias' speeches than Dover, but he readily acknowledges that for him the question of authenticity is secondary to the value of these speeches as historical documents.

${ }^{8}$ A good example is the question of publication itself, for which see also Worthington (1993). Rubinstein (2000) has undertaken to explore the idea of consultation in classical Athens.

9 Stephen Todd has produced the most authoritative accounts of the Lysianic corpus as a historically relevant and unique contribution to our knowledge of the fourth century BCE. See Todd (I993) and (2007), I-5 and 26-32 with further discussion and bibliography.

Io Todd (2007), 38 acknowledges this fact and offers a helpful - if necessarily very brief - overview of the kind of commentary tradition that Lysias' corpus has received from antiquity to contemporary times. It has always been one dominated by questions of style and rhetoric. 
BCE, but rather examine the importance of the persona of Lysias, how this name 'Lysias' became significant in rhetorical studies, what kind of rhetorical tradition it was associated with, and how understanding and treatment of Lysias and his work changed from the fourth to the first century BCE. This is no arbitrary choice, for the mentioned time frame captures the two crucial moments for the reception of Lysias and his corpus: the fourth century BCE that marks Lysias' activity as a speechwriter in Athens, and the first century BCE when critics indicate that Lysias has become a chief representative of the tradition of rhetoric which is primarily concerned with style. Dover had once demonstrated our inability to get hold of the historical Lysias and to assess the authenticity of his corpus, but this chapter moves further and looks at what is left of tò Nuolakóv (the 'Lysianic'), taking therefore a closer and more cautious look at the figure of 'Lysias' and his shadow in his contemporary fourth century $\mathrm{BCE}$ and later literaryrhetorical culture. Hence, without an ambition to tell a story of the practices and works of the historical person, this chapter will aim to ask (and answer) what is at stake in evoking the name (and author) Lysias.

\section{I.I Lysias ...}

Our primary evidence for Lysias' life is limited to the following sources: Lysias' speech I2 (Against Eratosthenes) and Against Hippotherses, Plato's Phaedrus, Cleitophon and the Republic, and Apollodorus' Prosecution against Neaira (\$\$2 I-3). ${ }^{\text {I }}$ Lysias' speech I 2 and Against Hippotherses (fr. 70 Carey), the latter of which survives in fragmentary form (we have roughly the last 200 lines of this speech), are generally taken to have been written by Lysias for his own court cases. The tone and first-person address make it highly likely that speech

${ }^{I}$ All references to the speeches of Lysias and to the extant fragments are based on Carey (2007). Even though Prosecution against Neaira circulated among the Demosthenic corpus, the speech was not written by him and was probably authored instead by Apollodorus. For more extended discussions of Lysias' biography, see Dover (I968), 28-46; and Todd (2007), I-I7 with further bibliography. 
I 2 was delivered by Lysias himself; Against Hippotherses, however, refers to Lysias in the third person which indicates that it had been delivered by someone else on his behalf. ${ }^{\mathrm{I} 2}$ Which of the speeches was first, is unclear and depends on how we interpret the ambiguous and lacunous evidence of Lysias' involvement in the restoration of democracy and - further whether and how we look at the broader context of his career (including his possible literary ambitions). ${ }^{\mathrm{I}}$

The two speeches tell us that Lysias was a son of Cephalus, a wealthy Syracusan who moved to Athens at the invitation of Pericles and lived there as a metic when Lysias was born (I 2.4:

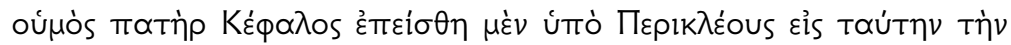
$\gamma \tilde{\eta} \nu$ ó $\phi ı \varepsilon \varepsilon \sigma \theta \propto l[\ldots]) .{ }^{\mathrm{I} 4}$ The family suffered greatly under the Thirty (the main topic of both speeches), though probably not losing all its fortune, for Lysias seems to have been able to still give substantial support to the democrats after having fled and been deprived of his family property (fr. 70, I63 ff.). It is generally believed that after the Thirty Tyrants were overthrown in $403 \mathrm{BCE}$, Lysias, in order to recover from financial

I2 For the complicated issue of Lysias' naturalization and the legal rights of metics or

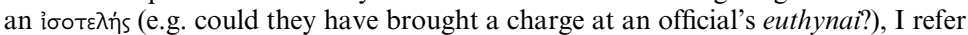
to Todd's excellent discussion (2007), I2-I7. Todd also points out an interesting possibility: even if Lysias was prevented from delivering speech I 2 in person, it is conceivable that he might have written the piece as if it was (meant to be) delivered and circulate it to show what he would have said on the occasion. Todd (2000), I I4, repeated in (2007), I3-I4.

13 Todd (2007), against Loening (I98I) and (1987), argues for an earlier composition date for speech I2, but readily admits that this is a genuine question which is difficult to answer satisfactorily. The question hangs largely on how to interpret lines $195^{-6}$ in fr. 70 which talk about building walls - is it building or rebuilding the walls? Both Indelli (2000), 203 and Medda (2003), I8I-8 argue for the later rebuilding, which would mean that the terminus post quem of Against Hippotherses is 394 BCE. The relative chronology of the two speeches does not play a crucial role in the following discussion, though it seems possible that the question of legal genre is more crucial to the discussion than Loening suggests. It is probable that Lysias could not, or would not want to, pursue a public trial to recover his property, especially as he has been branding himself as someone happy to invest in

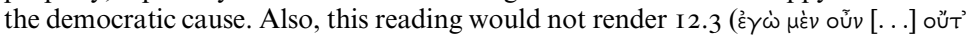

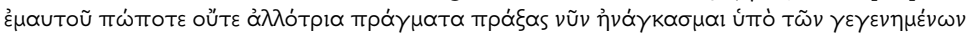

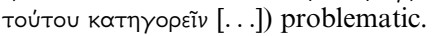

${ }^{14}$ Aside from speech I2, Dover (I968), 40-I shows that Against Hippotherses was probably an important source for later biographical accounts of Lysias' life and provided the information that could not be obtained from speech I 2 and Plato. On this fragmentary speech (and P.Oxy I606) see the recent edition by Medda (2003). 
difficulties, launched his career as a speechwriter. ${ }^{15}$ Thus, speech I2 Against Eratosthenes on the murder of his brother Polemarchus appears to be the earliest speech in the corpus, and certainly one of the outstanding moments to determine his writerly success. This speech is also one of our best sources for the events that took place in Athens under the Thirty, and the speech itself displays very strong democratic and antioligarchical language. We have no independent evidence of Lysias' political views, and it is very probable that this ideological language can be explained by the fact that at the time when the speech was delivered it was common to appeal to democratic values and governance in order to secure the benevolence of juries. ${ }^{\mathrm{I}}$ Nevertheless, the fact that speech I 2 exhibits these democratic sympathies in such vehement fashion and that these pro-democratic emotions come from one of the wealthiest metics in Athens might have played an important role for the subsequent image of 'Lysias'. ${ }^{17}$ Furthermore, it is conceivable that the political implication of Lysias' pro-democratic self-fashioning is also reflected in the reception of 'Lysias' in Plato and other philosophers.

The biographical tradition complicates the picture significantly in multiple ways. Dionysius of Halicarnassus is the author of the earliest, and most reliable, biography. He adds that at the age of fifteen Lysias left Athens with his brother Polemarchus to join the colonists at the founding of Thurii in Magna Graecia (D. H. Lysias I.2), but returned to Athens in 4I2/I I after being

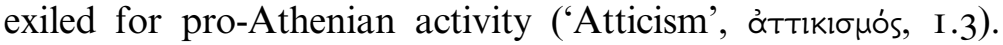
From this data, Dionysius adduces the birth date for Lysias to around $459 / 8$ and death to around $379 / 8$ or $378 / 7$. Ps. Plutarch's

${ }^{15}$ E.g. Shuckburgh (I979), I2; Carey (I989), 2-3; Edwards (I999), 2; Todd (2007), I3.

${ }^{16}$ Dover (I968), 47-56 on the impossibility to conclude anything about Lysias' own personal politics.

${ }_{17}$ The pro-democratic image is enhanced also by his Hippotherses where he draws attention to his benefactions towards the democratic counter-revolutionaries, and I wonder whether we might potentially add here also the spurious speech On His Personal Benefactions (frag. sp. LII), which is cited three times by Harpocration. Todd (2007), 6 is cautious and suggests that the latter might simply be an alternative title for the speech Hippotherses, but - whether this is true or not - it nevertheless draws further attention to Lysias' democratic outlook/commitments. 
account of Lysias' life is dependent on Dionysius' and supplemented by information derived from Lysias' speeches and other material. The most relevant, if also most problematic, addition is the association of Lysias with the teaching of Tisias and Nicias. The latter is an unknown name in Sicily, probably a textual corruption, ${ }^{\text {I8 }}$ but Tisias is - of course - famously linked to the early beginnings of rhetoric. The ancient tradition after Dionysius, who does not mention Lysias' possible connections to the Sicilian rhetoricians, ${ }^{19}$ continues to make references to the association of Lysias with rhetorical teaching (cf. Cicero Brutus 48).

The main complications added by the biographical tradition are twofold: first, there are some chronological challenges that emerge with dating Lysias' birth to as early as $459 / 8$, a tradition that seems to start with Dionysius and is followed by all other ancient sources. ${ }^{20}$ This early date is somewhat difficult to reconcile with the information we have about Lysias' life from Apollodorus, ${ }^{21}$ but it also poses difficulties for the dramatic date of Plato's Phaedrus. ${ }^{22}$ I would like to reiterate at this point that the question of the dramatic date is not in itself a problem, in as far as we are not trying to establish an actual or historical moment where Lysias would have met Phaedrus. There are plenty of historical inaccuracies, deliberate or not, in Plato's work to make it clear that Plato's attitude to his characters was not driven by aims for historical accuracy but rather by artistic and philosophical ambition. ${ }^{23}$ His envisioned character meetings were fictional and thus do not require us to

${ }^{18}$ Roisman et al. (2015), I25.

19 'Tisias and Nicias' in D. H. Lysias I is Usener's emendation based on Ps.-Plutarch.

${ }^{20}$ For a full-scale discussion of all challenges, see Todd (2007), 5-I7.

${ }^{21}$ Information about Lysias in his Against Neaira, dated to the 340 , suggests that if an earlier birth date is to be accepted, Lysias' mother would have lived to a very advanced age and Lysias was keeping a mistress in his late seventies. Not impossible, but quite unlikely. Dover (I968), 34-8; Todd (2007), Io.

${ }_{22}$ Dover (I968), 28-46; Nails (2002), I90-4, and 3 I4.

${ }^{23}$ Ancient sources have presented Plato's inaccuracies in anecdotal form. See, for example, Athenaeus II.505d reporting Gorgias' response to Plato's Gorgias or Diog. Laert. 3.35 about Socrates' own reaction to Plato's reading out loud his Lysis. See Riginos (I976), esp. 93-4 and 55. On Plato's playful use of historical characters, see Blondell (2002), 3I-7. 
conclude anything about an actual historical encounter. ${ }^{24}$ More important is the way in which Plato's imagined dramatic date contributes to the overall representation of the character in view. In our case, a dramatic date before 4I5 BCE (Dover's 4I 8-I6 BCE is an attractive proposal) would simply mean that Lysias spent quite some time in Athens between then and 403 BCE when he allegedly took up speechwriting without engaging with rhetoric or at least without leaving for posterity evidence of any such potential (rhetorical or otherwise) activity. And as such, it turns out that the question whether the dialogue is envisioned to take place in the early or late $4 \mathrm{IOS}$ is not in itself a major one.

The second, and arguably more problematic, question emerges from the representation of Lysias' rhetorical teaching and practice in that dialogue. The ancient evidence (the biographical tradition seems here in agreement with, or perhaps even dependent on, Plato's Phaedrus 228a2) presents Lysias as having engaged in rhetorical activity (either through studying or teaching) much earlier than the proposed start of his speechwriting career. ${ }^{25}$ Even though it is often acknowledged in modern scholarship, the biographical tradition is not a reliable source and, with the absence of any independent evidence, Lysias' possible pre-403 rhetorical activity is generally brushed aside. ${ }^{26}$ While it is indeed rather unlikely (and definitely not alluded to in the Phaedrus) that Lysias would have authored a technical handbook, Lysias' overall characterization in the dialogue seems to make more sense if we consider the possibility of Lysias having had a sort of intellectual or rhetorical following before his speechwriting career started soon after

${ }^{24}$ Even though Plato's characters are all (with the possible exceptions only of Callicles and Diotima) actual historical people. Blondell (2002), 3I; Nails (2002), 307-8; Graham (2007); Yunis (20II), 8.

${ }^{25}$ Suda $\lambda 858$ (Lys.) attributes a technical handbook to Lysias. Yunis (20I I), 8 takes this reference to rhetorical activity in the Phaedrus as support for the dramatic date of the dialogue as not much earlier than $403 \mathrm{BCE}$, thus not giving much weight to the possibility of Lysias having had a successful career in rhetoric before taking up speechwriting.

26 Todd (2007), I2 explains away the identification of Lysias with an established contemporary writer as his 'back-projection' from the time of writing. 
the restoration of democracy in $403 \mathrm{BCE}^{27}$ An independent source that seems to corroborate this view is Apollodorus' Against Neaira, where Lysias is referred to as a sophist (бофıбтn's, §2I). ${ }^{28}$ Whether or not we should accept this detail about Lysias' possible rhetorical activity in Athens before 403 $\mathrm{BCE}$, it is clear that the closer the dramatic date is to $403 \mathrm{BCE}$, the more time Lysias has had to gain reputation in Athens and thus to deserve the wholehearted praise of Phaedrus as one of

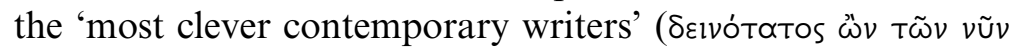
үрóфııı, 228a2).

\section{I.2 ... and the Corpus Lysiacum}

Let us move on from Lysias' life to his output. Estimating by the number of speeches attributed to Lysias by the first century $\mathrm{BCE}$, he was either extremely prolific (especially given his 'late' start) and/or highly regarded enough to be used as a 'mark of quality' to raise the literary status of speeches written by others. In fact, the number of items (425) attributed to him in antiquity makes him by far the most productive speechwriter; the number of speeches that are attributed by Ps. Plutarch to other Ten orators, for instance, never exceeds 75 . $^{29}$ In comparison with the 233 speeches that Dionysius accepted as genuine in the first century BCE, our modern editions present 34 or 35 speeches, plus fragments which in

${ }^{27}$ Accepting the tradition of Lysias as somehow active in the rhetorical scene of the day also gives Plato another playful inconsistency in his presentation of Lysias. Namely, in the beginning of the dialogue Lysias is portrayed as an entertainer and borderline teacher of rhetoric, while in the later part of the dialogue reference is made to his logographic activity (257c5). Is he both? At any rate, Plato's Phaedrus seems to be the first place where Lysias' rhetoric is discussed as extending to two different genres, the playful display discourse and the court speech.

${ }^{28}$ So does Cicero's Brutus (48), though this is certainly not independent from Plato's Phaedrus.

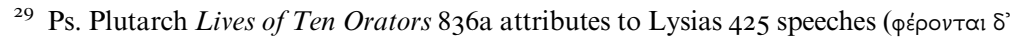

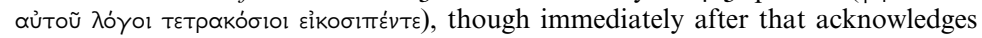

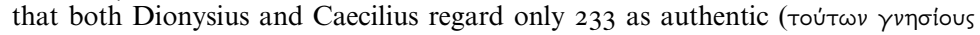

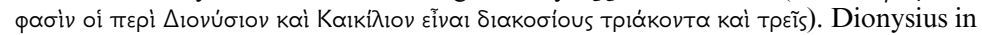
his Lysias claims more vaguely that Lysias has written 'no less than two hundred

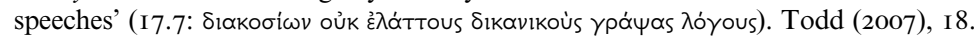


the most recent OCT edition amount to $\mathrm{I} 45 .^{30}$ All of the preserved speeches are contained in Codex Palatinus Graecus 88 , now by scholars unanimously designated as MS X, which dates to the late twelfth or early thirteenth century. ${ }^{3 \mathrm{I}} \mathrm{X}$, the archetype of the majority of our medieval manuscripts, was organized largely by legal action, ${ }^{32}$ and was very probably based on an anthology, which also contained orations by other Attic orators. ${ }^{33}$

A brief look at the entire corpus Lysiacum, which I take here to encompass all titles attributed to Lysias in antiquity, reveals Lysias as an author competent in a variety of rhetorical genres and legal proceedings. This tradition should be treated, however, with caution and no doubt some attributions go back to biographical details that have been attached to Lysias' life and were later accepted as facts about his literary output. ${ }^{34}$ In antiquity, Lysias was credited with: ${ }^{35}$

I Display (epideictic) speeches, e.g. 'Emıт́丿 plos (speech 2),

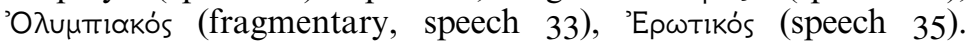
Given the importance of Plato's Phaedrus for the reception of Lysias, most references to this category of epideictic speeches primarily discuss, or depend on, the 'Epwtıkós.

${ }^{30}$ As Todd (2007), I8 notices, the distinction between fragments and speeches is not always very clear-cut: speech 35 , for instance, is the Lysianic speech from the Phaedrus (probably written by Plato and not Lysias), and speech 32 is really a fragment from Dionysius' essay Lysias.

${ }^{31}$ Sosower (1987) discusses the medieval and Renaissance manuscript tradition of Codex Palatinus Graecus 88. Some of the problems of this work are briefly highlighted in MacDowell (1988).

${ }^{32}$ Carey (2007), ix. Cf. also Dover (I968), Io.

33 Sosower (1987), 4 labels it the hyperarchetype $\Omega$. Carey (2007), x proposes that this anthology could either have been composed in the fourth century CE ('at a time when the range of reading in general was narrowing'), or, alternatively, that 'it was made earlier but initially had limited influence on the readership', and concludes that both hypotheses are plausible and consistent with the evidence of the papyrus fragments.

34 This is probably a parallel development to the treatment of ancient poets, whose works were frequently used to reconstruct details about their personal lives. The central work on this subject is Lefkowitz (20I2).

35 In the following classification I will review items that have been associated with or attributed to Lysias in antiquity, which will shed light on the ancient perception of his versatility as a writer. This is why speeches whose authenticity has been doubted (e.g. the 'Epwtikós from the Phaedrus which has been moved to the corpus by modern editors who, however, generally dispute its authenticity) are on this list. 
2 Dionysius preserves an example of a public or deliberative speech,

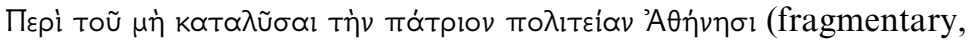
speech 34). It is difficult to imagine, however, how or in what circumstances this speech could have been delivered by Lysias.

3 Various sources suggest that Lysias authored letters and other writings of private content. ${ }^{36}$ Dionysius of Halicarnassus announces rather unexpectedly that he is not interested in Lysias' letters, amatory discourses or the other works, because he wrote them for amusement ( $\mu \varepsilon \tau \dot{\alpha} \alpha \pi \alpha \delta \delta \tilde{\alpha} s) .{ }^{37}$ This is surprising indeed, especially since Dionysius was not interested in the legal argumentation but in Lysianic style and one would think that having access to variety of genres would have given Dionysius an even better and broader overview of Lysias' art. This conundrum will be taken up with the closer examination of Dionysius' criticism below.

4 Both Ps. Plutarch (836b) and the Suda suggest that Lysias wrote a handbook or technical treatise on rhetoric. This, along with Lysias' possible rhetorical activity, will be discussed below.

5 The most important group of Lysias' writings are his private courtroom speeches, which, within the boundary of private speeches, encompass a whole host of writings for different legal procedures. For the present purpose it is not necessary to divide these speeches further according to their underlying legal issues; it suffices to acknowledge that even within the category of private speeches Lysias seems to have been regarded as a competent writer on, for instance, cases regarding public/personal offense, murder or examinations for the holders of public offices. ${ }^{38}$

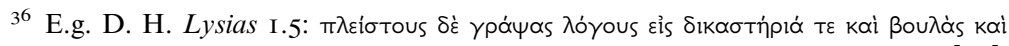

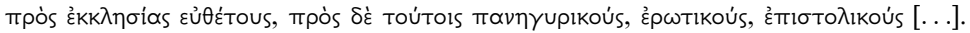

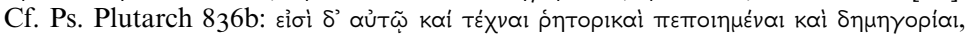

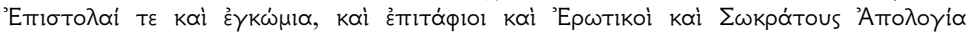

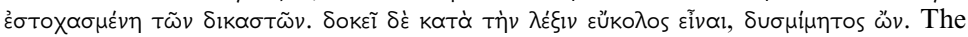

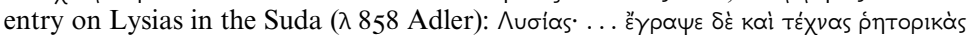

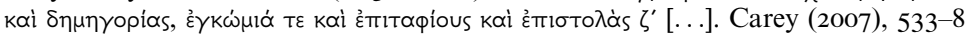
collects references to Lysias' letters.

37 D. H. Lysias 3.7. Blass (I887), 374-5 counts Lysias' speech in the Phaedrus in this

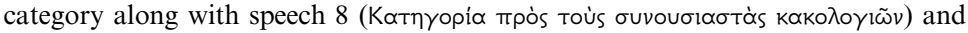
some titles from Harpocration that indicate intimate content. In the context of the Phaedrus, however, Lysias' speech seems to function more as a display of rhetorical

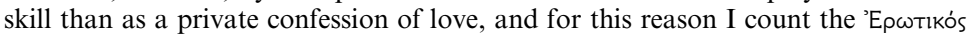
within the first category of display speeches.

${ }^{38}$ Blass (I 887), 357-75 divides all existing evidence of Lysias' intellectual output (including spurious fragments and letters) into four broad categories ( $\lambda$ óyol

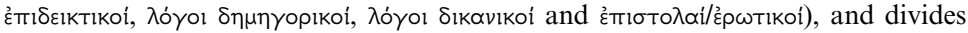
the 'law court speeches' ( $\lambda$ ó

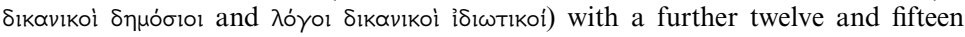


As this list demonstrates, Lysias' speeches attest to a variety of rhetorical genres and legal procedures and, for this reason, it has been pointed out that Lysias' surviving work shows a broader range of litigation than what we see in any other orator or speechwriter of the time. ${ }^{39}$ This aspect of Lysias' writings is often overlooked in modern scholarship, where Lysias is mostly regarded as a writer of forensic speeches. ${ }^{40}$ There are two main reasons for this: first, the fact that, with the exception of 'Eтıт́́ by modern scholars), the majority of the Lysianic corpus that has come down to us consists of private speeches. The second reason, which is possibly directly related to the first, is that Lysias' fame in the first century BCE seems to have rested primarily on his forensic speeches and our prime witness for this view is Dionysius of Halicarnassus, who is not particularly interested in the legal procedures of the various private speeches (which would show Lysias' capability in different legal contexts) but focuses mainly on the literary quality and style of Lysias' writing. ${ }^{4 \mathrm{I}}$ More specifically, Dionysius is interested in a very particular kind of style, and he finds the prime examples for this 'simple and effective' rhetoric in Lysias' private speeches. However, the ancient tradition (other than Dionysius) shows a close awareness of, and interest in, legal procedures. The Alexandrian edition of Lysias, for example, was organized broadly based on the underlying legal issue. ${ }^{42}$

The corpus Lysiacum brings together rhetorical writing at a rather large scale - from court speeches for a variety of juridical matters to epideictic speeches and a personal speech (speech I2) that allegedly gives us a sense of Lysias' own voice

different divisions each. Constructing such detailed categorizations, while helpful, is not the aim of this chapter.

39 Cf. Todd (2007), 3-4.

40 See, for instance, Usher's discussion $(1976,32)$ where he claims: 'While primarily a forensic speechwriter, Lysias was famous enough as an epideictic orator to have commanded an audience at Olympia in $388 / 7$ [...]'.

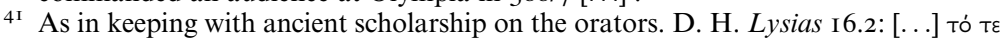

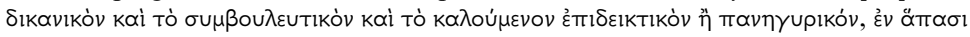

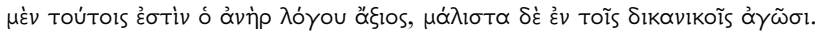

42 Carey (2007), viii. 


\section{... and the Corpus Lysiacum}

early in his career. Despite the large variety of texts that constitute the corpus at the moment, we should also remember that we do not even have Io per cent of the corpus that was available for ancient critics. In fact, none of the speeches cited and discussed by Dionysius of Halicarnassus, the most prominent critic of Lysias' rhetoric, have come to us through the manuscript tradition. From all this we can infer that Lysias was an important writer of the late fifth and fourth centuries BCE, even though we would be also justified to wonder how much we would know about Lysias and his work had there not been one text in particular that did much to immortalize his figure to the history of rhetoric - Plato's Phaedrus. 